\title{
Bitkilerde Abiyotik Stres Koşullarında Selenyum Metabolizması ve Fizyolojik Etkileri
}

\author{
İlkay Yavaş ${ }^{1 *}$ Volkan Mehmet Çınar² Aydın Ünay ${ }^{3}$ \\ ${ }^{1}$ Aydın Adnan Menderes Üniversitesi Koçarlı MYO, Bitkisel ve Hayvansal Üretim Bölümü, Aydın (ORCID: 0000-0002-6863-9631) \\ 2 Aydın Adnan Menderes Üniversitesi Fen Bilimleri Enstitüsü, Tarla Bitkileri ABD, Aydın (ORCID: 0000-0001-5822-5649) \\ ${ }^{3}$ Aydın Adnan Menderes Üniversitesi Ziraat Fakültesi, Tarla Bitkileri Bölümü, Aydın (ORCID: 0000-0002-7278-4428)
}

(İlk Geliş Tarihi 6 Şubat 2020 ve Kabul Tarihi 31 Mart 2020)

(DOI: 10.31590/ejosat.685702)

ATIF/REFERENCE: Yavaş, İ., Çınar, V. M. \& Ünay, A. (2020). Bitkilerde Abiyotik Stres Koşullarında Selenyum Metabolizması ve Fizyolojik Etkileri. Avrupa Bilim ve Teknoloji Dergisi, (18), 840-849.

Öz

Selenyumun (Se) özellikle abiyotik stres koşullarındaki bitkilerde antioksidan rol oynamakla birlikte biyofortikasyonda yer almaktadır. Düşük dozlarda büyüme ve gelişmeyi teşvik etmekte buna karşın yüksek dozlarda toksik etkide bulunmaktadır. Bu derlemede selenyumun tuzluluk, yüksek sıcaklık ve kuraklık gibi stres koşullarındaki fizyolojik etkileri, topraktaki yarayışlılığı ve alım mekanizması üzerinde yoğunlaşılmıştır. Toprakların selenyum içeriğinin, toprak tekstürü, organik madde, redoks potansiyeli, $\mathrm{pH}$ ve kil içeriğine bağlı olduğu belirlenmiştir. Bitkilerin selenat ve selenit gibi inorganik formdaki selenyum ile selenosistein ve selenometionin gibi organik formdaki selenyumu aldığı görülmüştür. Selenyum alımı ve metabolizmasının bitki türüne, büyüme dönemine ve bitki organına bağlı olarak değişebilir. Düşük dozlarda selenyumun selenoprotein sentezini düzenlediği, antioksidan fonksiyonunu artırdığı ve bitkileri sıcaklık, kuraklık, UV-B, tuzluluk ve ağır metal stresi gibi çeşitli abiyotik streslere karşı koruduğu belirlenmiştir.

Anahtar Kelimeler: Abiyotik stres, selenat, selenit, selenometionin, selenosistein

\section{The Physiological Effects and Metabolism of Selenium in Abiotic Stress Conditions in Plants}

\begin{abstract}
Selenium (Se) plays an antioxidant role especially in plants under abiotic stress conditions. At the same time this element is included in biofortification. It promotes growth and development at low doses, but at high doses it is toxic. This review focuses on the physiological effects of selenium under stress conditions such as salinity, high temperature and drought, its availability in soil and the mechanism of uptake. It was determined that the selenium content of soils is dependent on soil texture, organic matter, redox potential, $\mathrm{pH}$ and clay content. The plants can uptake organic form of selenium such as selenocysteine and selenomethionin and inorganic selenium forms such as selenate and selenite. Selenium intake and metabolism can vary depending on the plant species, growth period and plant organ. It was emphasized that Se regulates the synthesis of selenoprotein, increases the antioxidant function and protects plants against various abiotic stresses such as temperature, drought, UV-B, salinity and heavy metal stres at low selenium concentrations.
\end{abstract}

Keywords: Abiotic stress, selenate, selenid, selenomethionine, selenosisteine

\footnotetext{
* Sorumlu Yazar: Aydın Adnan Menderes Üniversitesi Koçarlı MYO, Bitkisel ve Hayvansal Üretim Bölümü, Aydın, Turkey, ORCID: 0000-00026863-9631, iyavas@adu.edu.tr, Tel: +90 (256) 77273 48, Fax: +90 (256) 7727460
} 


\section{Giriş}

Küresel iklim değişikliği çok sayıda faktöre bağlı olarak kültür bitkileri üzerindeki baskısını artırmaktadır. Bu nedenle abiyotik stres faktörlerinin bitkiler üzerindeki olumsuz etkilerini azaltmak için çok sayıda araştırma yürütülmektedir. Birçok bitkide selenyumun farklı fizyolojik etkiler ve mekanizmalar üzerinden olumsuz etkileri hafiflettiği ortaya konulmuştur. Selenyum, önemli antioksidan enzim olan selenoproteinleri oluşturabilmek amacıyla proteinlere bağlanmaktadır. Çevresel stres koşullarında düşük dozlarda selenyum selenoprotein sentezini düzenleyerek antioksidan fonksiyonunu artırmakta, yaşlanmayı geciktirmekte, bitki gelişimini teşvik etmekte, kurak koşullarda bitki su durumunu düzenlemekte ve kloroplastlarda nişasta birikimini artırmaktadır (Goldhaber, 2003; Feng vd., 2009; Gökbulut, 2010). Buna karşın yüksek dozlarda amino asitlerdeki kükürt ile yer değiştirilebileceği için toksik olduğu ve proteinlerin üç boyutlu yapısını değiştirerek enzimatik fonksiyonları bozduğu hatta bitkilere zarar verdiği bildirilmiştir (Ekelund ve Danilov, 2001; Hashem vd., 2013; İbrahim ve İbrahim, 2016). Kaçar ve Katkat (1998) genellikle selenifer olmayan toprakların toplam Se içeriklerinin $0.1-2.0 \mathrm{mg} \mathrm{kg}^{-1}$ arasında değiştiğini buna karşın selenifer toprakların Se içeriklerinin ise $10 \mathrm{mg} \mathrm{kg}^{-1}$ değerine ulaşabileceğini belirtmiş̧ir. FAO raporlarına göre ülkemiz toprakları düşük Se içerikli topraklar olarak gösterilmiştir (Sillanpää ve Jansson, 1992). Buna karşın, Türkmen (2010) ülkemizde sarımsak yetiştirilen 7 ildeki toprakların Se içeriğinin 1.32 ile $11.16 \mu \mathrm{g} \mathrm{kg}^{-1}$ arasnda değiştiğini ve $50 \mu \mathrm{g} \mathrm{kg}^{-1}$ altında olduğu için selenifer olmayan topraklar sınıfında yer aldığını saptamıştır.

Selenyum, bitki büyümesini teşvik etmesi nedeniyle bitkilere faydalı bir element olarak kabul edilmektedir. Köklerde birikmekte ve bitkilerde L-selenometiyonin (SeMet) ve benzeri türlere dönüştürülmektedir. Bitkiler için yararlı içeriği bitki türlerine bağlı olarak değişmektedir. Yaklaşık 25 bitki cinsi selenyum akümülatörü olarak gruplandırılmaktadır. En büyük hiperakümülatör olarak Brassicaceae (Stanleya), Fabaceae (Astragalus) ve Asteraceae (Xylorhiza, Oonopsis, Symphyotrichum) bitki grupları gösterilmiştir (Cappa vd., 2014; Harris vd., 2014). Bu bitkiler toksisite belirtileri göstermeden, 100-1000 mg kg-1 kuru maddeye kadar Se biriktirebilmektedirler. Tahıllar içerisinde ise en etkili Se akümülatörü olarak buğday bitkisi gösterilmiştir (Lyons vd., 2003). Ülkemizde yapılan çalışmalarda, farklı coğrafik bölgelerden toplanan buğdayların ortalama $34 \mu \mathrm{g} \mathrm{kg}^{-1}$ selenyum içerdiği saptanmıştır (Çakmak vd., 2009). Irmak ve Semercioğlu (2012) ise Çukurova bölgesinde içeriğin 11.3 - $626.9 \mu \mathrm{g} \mathrm{kg}^{-1}$ arasında değiştiğini ve toprak Se varlığı ile tane içeriği arasında anlamlı bir positif ilişki olduğunu vurgulamışlardır. Hiperakümülatör olmayan bitkiler (sebzeler ve patates) dokularında ancak $100 \mathrm{mg} \mathrm{kg}^{-1}$ kuru maddeye kadar Se depolayabilirler (Natasha vd., 2018). Selenyumun hem selenit hem de selenat formlarında hiperakümülatör ve indikatör bitki türlerine uygulanması ağır metal stresinin etkilerinin azalmasına neden olmaktadır. Genellikle indikatör olarak kabul edilen monokotiledon bitkilerde koruyuculuğu teşvik etmek için daha düşük dozlarda selenyum $(2-15 \mu \mathrm{M})$ uygulanırken, hiperakümülatör olarak dikotiledon bitkilerde bu maddelerin daha yüksek seviyelerine (800 $\mu$ M'i aşan) ulaşılmaktadır (Sieprawska vd., 2015). Selenyum alımı ve metabolizması bitki türüne, büyüme dönemine ve bitki organına göre değişmektedir. Brokoli bitkisi selenometil-SeCys (SeMeSeCys) formunda selenoamino asitlerin büyük çoğunluğu ile yüksek oranda selenyum biriktirmektedir ve bitkilerin büyük bir çoğunluğu yaprak ve sürgünlerinde köklerinden daha fazla selenyum biriktirmektedirler. Buna karşın patatesin kök, stolon ve yumrularında selenyum içeriğinin selenyum gübrelemesi ile arttığı gözlenmiştir (Turakainen, 2006). Hamilton (2004) düşük selenyum içeriğinin normal büyüme ve gelişme için gerekli olduğunu ve orta dozlarda homeostatik fonksiyonların sürdürülmesinde, artan içeriklerinin ise toksik etki ile sonuçlanacağını vurgulamıştı. Selenyum uygulamasının buğdayda bitki su içeriğini düzenlediği, arpada azot asimilasyonunu, soyada sürgün kuru madde üretimini, patateste yumru kalitesini artırdığı saptanmıştır (Hasanuzzaman vd., 2010).

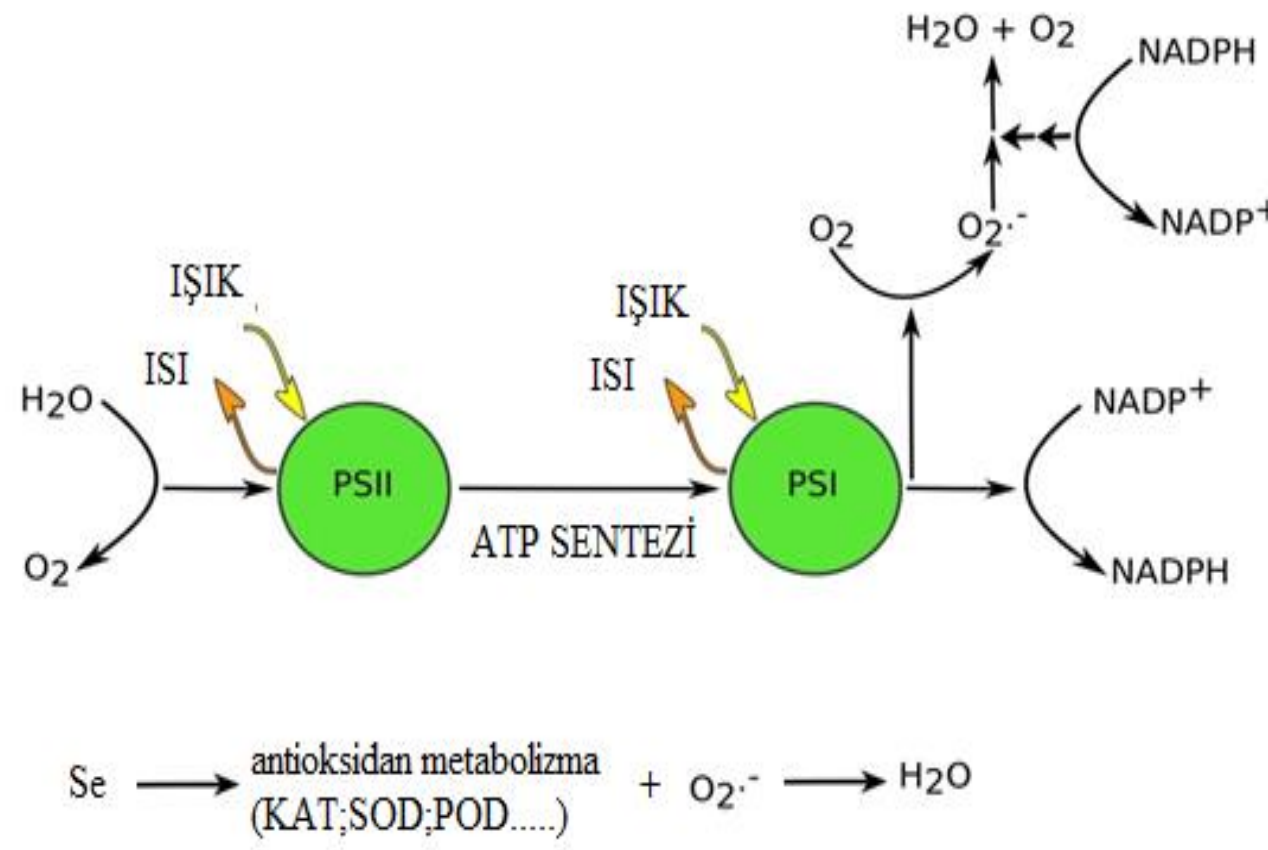

Şekil 1. Fotosentez ışık reaksiyonlarında oksidatif stresin oluşumu (Skillman vd., 2011 den değiştirilerek). 
Şekil 1 de görüldüğü gibi normal koşullar altında fotosistem II'den fotosentetik elektron iletimi ile NADP ${ }^{+} \mathrm{NADPH}^{\prime}$ a indirgenir. Ancak aşırı 1şık koşullarında $\mathrm{O}_{2}$ süperoksit radikaline $\left(\mathrm{O}_{2}^{--}\right)$indirgenir. Bitkide selenyum varlığ onarılması (Şekil 1), hücre zarı ve kloroplast bütünlüğü gerçekleşir ve buna bağlı olarak fotosentez kapasitesinde artış gibi birçok fizyolojik olayda yer almaktadır. Aynı zamanda, selenyum antioksidan sistemlerde gerekli olan elementlerin alımını ve reorganizasyonunu düzenler, hücrenin iyon dengesini ve yapısal bütünlügünü korur ve fotosentezde görev yapan bileşikleri olumlu yönde etkileyerek elektron taşınımında etkili olmaktadır. Tarımsal olarak ise yaşlanmanın gecikmesi ve bitki veriminde artış ön plana çıkmaktadır (Natasha vd., 2018). Selenyum, topraktaki yarayışlılığına veya dışarıdan Se uygulamasındaki doza bağlı kalarak bitkilerde iki yönlü etkide bulunabilir. Tüm fizyolojik olaylardaki olumlu etkilerine karşın yüksek düzeyde Se varlığı bitki metabolizmasında düzensizliklere yol açar ve klorofil içeriğinin azalmasına neden olurken, düşük veya optimum selenyum miktarı bitkilerde klorofil içeriğini artırabilir. Börülce (Manaf, 2016), dereotu (Shekari vd., 2015), tütün (Jiang vd., 2015), arpa (Valkama vd., 2003), maş fasulyesi (Malik vd., 2012) gibi çok sayıda kültür bitkisinde optimum düzeyin üzerinde selenyum nedeniyle yapraklarda klorofil içeriğinin engellendiği belirtilmiştir. Selenyumun neden olduğu toksik etkilerin çoğu, ROS (serbest oksijen radikalleri) üretimi ile ilişkilidir. Yüksek düzeyde Se varlığında artan ROS üretimi hücre zarını ve hücre proteinlerinin yapısını ve fonksiyonunu bozmaktadır. Selenyum özellikle $\mathrm{O}_{2}^{--}$(singlet oksijen) gibi serbest radikalleri oluşturmak için tiyoller ve glutatyon (GSH) ile reaksiyona girmektedir (Feng vd., 2013; Natasha vd., 2018). Selenyum glutasyon peroksidaz enziminin yapı taşıdır ve her bir mol enzim $4 \mathrm{~g}$ Se atomu içermekte ve peroksitlerin toksik etkilerini önleyerek hücre membranlarını korumaktadır (Brown ve Arthur, 2001; Harmankaya, 2009). Bitkilerde önemli bir antioksidan olan glutatyon yüksek selenyum stresinde azalmakta ve ROS birikimi artmaktadır. Yüksek Se stresinde üretilen ROS, plazma membran lipitleri ve yağ asitleri ile etkileşime girebilmekte ve bu şekilde lipit peroksidasyonuna yol açabilmektedir. Benzer şekilde, yüksek dozda selenyum kaynaklı lipid peroksidasyonu düşük dozlarda selenyum bir antioksidan görevi gördüğü için engellenmektedir (Feng vd., 2013; Natasha vd., 2018).

$\mathrm{Bu}$ derlemede, Se alımı, fizyolojik fonksiyonları ve stres koşullarında özellikle kültür bitkileri üzerine etkilerinin ortaya konulması amaçlanmıştır. Öte yandan selenyumun strese toleransla ilgili bazı gen gruplarının bir aktivatörü olabileceği değerlendirilmiştir.

\section{Bitkilerde Selenyum Alımı ve Metabolizması}

Bitkiler element formundaki selenyumu suda çözünmediği için doğrudan alamamakta fakat inorganik selenyum [Se (IV), Se (VI)] ve selenosistein (SeCys) ve selenometionin (SeMet) gibi organik selenyum formlarını alabilmektedirler (Harmankaya, 2009; Gökbulut, 2010; Natasha vd., 2018). Selenometioninlerin protein yapısında olması nedeniyle tahıllarda daha yüksek miktarda selenyum bulunmaktadır. Oksidasyon düzeyi ve toprak pH'sı arttıkça Se bitkiler tarafindan daha kolay alınmaktadır (Harmankaya, 2009). Ayrıca toprağa uygulanan selenyumun çok az bir kısmı (<5\%) bitki tarafından kullanılabilmektedir. Selenat kök hücresinde plazma membranına kükürt taşıyıcıları aracılığı ile girmektedir. Bu nedenle toprağa kükürt ilavesi bitkiler tarafından selenyum alımını sınırlamaktadır. Asitli topraklarda kükürtün farklı formlarının (sülfür, sülfit, sülfid ve metionin) bitkilerde selenyum alımını azalttığı fakat alkali topraklarda durumun tam tersi olduğu vurgulanmıştır. Selenit büyük olasılıkla fosfor taşıyıcılar ile taşınmakta ve bitkilerde alım için rekabete girmektedir. Tüm bunlara bağlı olarak kükürt ve fosforun varlığı bitkilerde selenyum alımını azaltmaktadır. Bitkilerde birikim sonrası selenyum, S içeren proteinler ile birlikte kükürt ile rekabete girmektedir. Selenyum kükürt ile yer değiştirdikten sonra sistein selenosisteine dönüşmektedir (Natasha vd., 2018).

Köklerde birikimi yüksek olan kurşun, kadmiyum, nikel ve krom gibi metallerin aksine selenyum öncelikle sürgünlerde birikmektedir. Şekil 2'de görüleceği gibi selenyumun köklerden toprak üstü aksamlara taşınımı bitki türüne ve toprakta ya da büyüme ortamında mevcut olan selenyum formuna bağlı olarak değişmektedir. Selenit, Se (VI) ile kıyaslandığında sürgünlerde daha az birikmekte, sürgünlerde en fazla Se taşınımı Se (VI) formunda gerçekleşmektedir. Se (IV), bitkide birikim sonrası kolay bir şekilde organik forma dönüşürken, Se (VI) oldukça yavaş ve az miktarda dönüşmektedir. Bitki köklerine uygulanan Se (VI)'nın yarısından fazlası sürgünlere taşınırken, Se (IV), köklerde kalmaktadır (Şekil 2). 


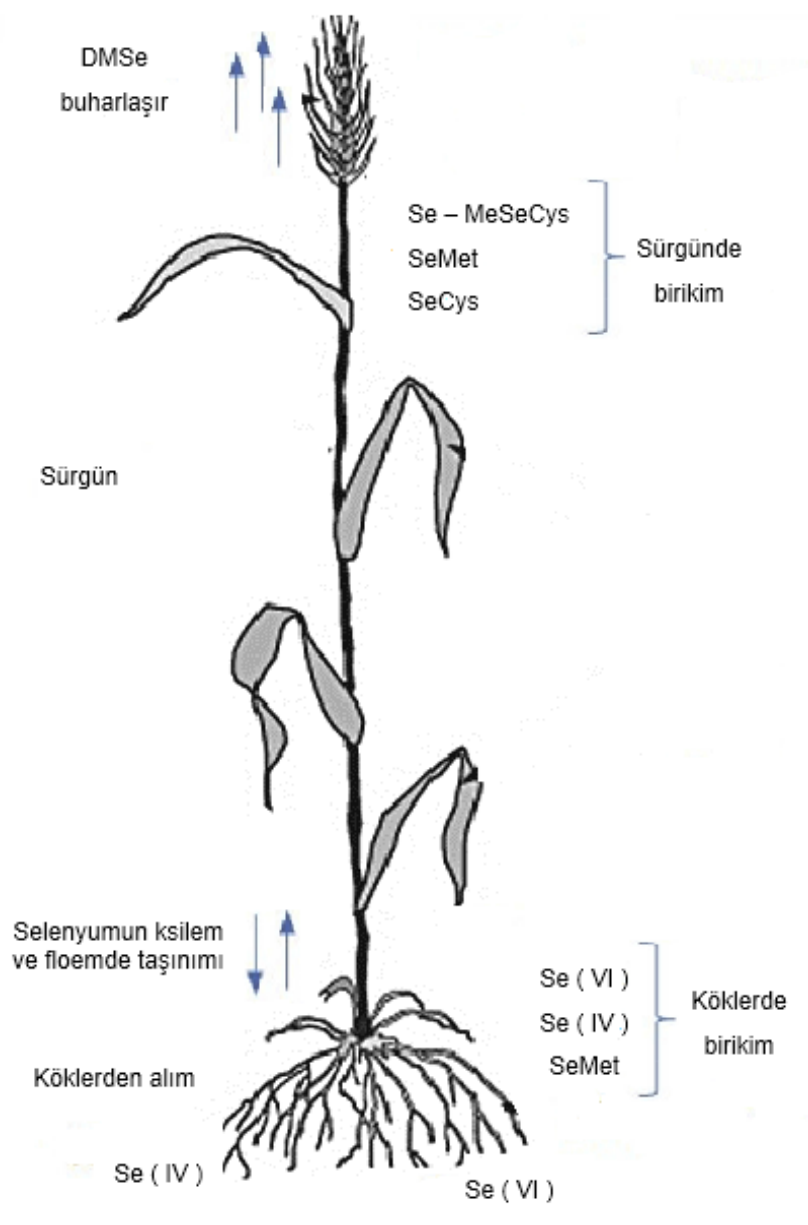

Şekil 2. Farklı bitki dokularında selenyum türlerinin birikimi.

Kikkert ve Berkelaar (2013), buğday ve kanolada Se taşınımının Se(VI) > SeMet > Se(IV) / SeCys şeklinde olduğunu vurgulamışlardır. Carey vd. (2012), çeltik tanesine SeMet ve SeMeSeCys taşınımının Se (IV)'te Se (VI)'ya oranla daha etkin olduğunu bildirmişlerdir. Selenat, önce sürgünlerden köklere ksilem ile taşınmakta ve Se (VI)'un miktarı ksilemde 6-13 kat artmaktadır. Carey vd. (2010), çeltikte organik selenyumun (SeMet ve SeMeSeCys) floem, buna karşılık inorganik selenyumun [Se (IV) ve Se (VI)] hem ksilem hem floem aracılığı ile taşındığını vurgulamışlardır. Organik selenyum türleri, floeme hızlı bir şekilde yüklenmekte ve inorganik türlere nazaran taneye daha etkin bir şekilde taşınmaktadır. Se (VI) ksilem aracılığı ile doğrudan iyonik forma dönüşmekte ve taşınım sağlanmakta iken, Se (IV) önce organik forma dönüşmekte daha sonra ksilem aracılığı ile sürgünlere taşınmaktadır. Organik formu inorganik forma çeviren bitkiler arasında arpa, buğday, şalgam ve ayçiçeği gibi bitkiler gelmektedir (Gökbulut, 2010). Bitkilerde selenyum birikimi farklı kimyasal formlarda ve farklı dokularda gerçekleşmektedir (Şekil 2). SeMet, buğday, arpa ve çavdar gibi çoğu tahılda baskın olan Se türleri olup, toplam Se'nin \% 60-80'ini oluşturmaktadır (Zu vd., 2009).

Bazı araştırıcılar ışı stresi altında patates bitkisinde (Seppänen vd., 2003), UV-B stresinde buğdayda (Yao vd., 2011), su stresinde ak üçgülde (Wang, 2011) ve yüksek sıcaklık stresinde tane sorgumda (Djanaguiraman vd., 2005) bitkilere Se ilavesinin, SOD aktivitesini artırdığını vurgulamışlardır. Ayrıca Hartikainen ve Xue (1999) selenyumun UV kaynaklı oksidatif strese karşı bitkileri koruduğunu hatta yüksek ışınlamalarda bitki büyümesini teşvik ettiğini vurgulamışlardır. UV ışınlarına maruz kalan Euglena gracilis'te de selenyumun olumlu etkileri gözlenmiştir (Ekelund ve Denilov, 2001). Selenyum dozuna paralel olarak bitkilerde süperoksit dismütaz (SOD) aktivitesi artmaktadır. Bunun nedeni olarak toksik olabilecek selenyum dozuna bir tepki olarak serbest oksijen türevlerindeki artış gösterilmiştir. Benzer olarak, glutatyon, askorbat ve tokoferol gibi düşük molekül ağırlığına sahip maddeler ve katalaz (CAT), askorbat peroksidaz (APX), glutatyon peroksidaz (GSH-Px) guaikol peroksidaz (GR) ve askorbat glutatyon (AsA) gibi diğer tip enzimler bitkinin serbest oksijen radikallerini dengelemek için sentezlenirler. Bu antioksidanlar, hidrojen peroksit $\left(\mathrm{H}_{2} \mathrm{O}_{2}\right)^{\prime}$ in zararsız hale getirilmesinden sorumludurlar. Stres koşullarında bitkilerde Se'nin APX ve katalaz (CAT) enzimini, özellikle de CAT'i önemli bir şekilde etkin hale getirdiği gözlenmektedir. Optimum düzeydeki Se ilavesinin, antimon (Sb) stresi koşullarında çeltik bitkisi, kurşun $(\mathrm{Pb})$ stresinde bakla bitkisi, tuz ve kuraklık stresi koşullarında kolza bitkisi ve yüksek sıcaklık stresinde sorgum bitkisinde malondialdehit birikimini engellediği gözlenmiştir. Bitkiler çevresel strese maruz kaldıklarında, kloroplastlar zarar görmekte ve bu da fotosentezin olumsuz yönde etkilenmesine neden olmaktadır. Bununla birlikte, uygun Se miktarının eklenmesi kloroplastlara verilen zararı azaltabilir ve klorofil içeriğini artırabilir. Bununla birlikte, fazla Se, bitkilerde fotosentez sistemine zararı artırabilir, engelleyebilir ve fazla nişasta üretimi ile sonuçlanabilir (Feng vd., 2013).

Hücresel bitki solunumunda, organik bileşikler oksitlenerek ATP formunda kullanılabilir kimyasal enerjiye dönüşmektedir. Bu olayın merkezinde mitokondride yer alan elektron taşıma sistemi (ETS) bulunmaktadır. Bu, NADH dehidrogenaz (kompleks I), 
süksinat dehidrogenaz (kompleks II), sitokrom c redüktaz (kompleks III) ve sitokrom c oksidaz (kompleks IV) gibi 4 oksidoredüktaz kompleksinden oluşmaktadır (Şekil 1). Ayrıca bu sistemde sitokrom c ve lipid ubiquinon gibi 2 hareketli elektron taşıyıcısı yer almaktadır. Genel olarak, elektronlar NADH veya FADH2 koenzimlerinden suya indirgenmiş moleküler oksijene aktarılmaktadır. Dört oksidoredüktaz kompleksinden üçü (kompleks I, III ve IV) elektron transfer reaksiyonlarını iç mitokondriyal zar boyunca proton translokasyonu ile birleştirmektedir. Sonuç olarak, ADP'nin fosforilasyonu için ATP sentaz kompleksi (kompleks V) tarafından kullanılabilecek bir proton gradyanı oluşturulmaktadır. Klasik olarak açıklanan formunda, hücresel solunum, doğrusal bir ETS'ye (NADH'den I, III ve IV kompleksleri yoluyla moleküler oksijene kadar) dayanmaktadır. Bununla birlikte, elektronlar ETS' ye birkaç alternatif noktada girebilmektedir. Bu özellikle çok dallı olan bitki ETS sistemi için geçerli olmaktadır (Schertl ve Braun, 2014).

\section{Abiyotik Stres Koşullarında Selenyum}

Bazı araştırıcılar 1şık stresi altında patates bitkisinde (Seppänen ve ark., 2003), UV-B stresinde buğdayda (Yao ve ark., 2011), su stresinde ak üçgülde (Wang, 2011) ve yüksek sıcaklık stresinde tane sorgumda (Djanaguiraman ve ark., 2005) bitkilere Se ilavesinin, SOD aktivitesini artırdığını vurgulamışlardır. Ayrıca Hartikainen ve Xue (1999) selenyumun UV kaynaklı oksidatif strese karşı bitkileri koruduğunu hatta yüksek ışınlamalarda bitki büyümesini teşvik ettiğini vurgulamışlardır. UV ışınlarına maruz kalan Euglena gracilis'te de selenyumun olumlu etkileri gözlenmiştir (Ekelund ve Denilov, 2001). Se'ye maruz kalan bitkilerde süperoksit dismütaz (SOD) aktivitesini etkileyen ikinci faktör ise, Se'nin dozudur. SOD aktivitesindeki artış, Se'nin toksisitesi nedeniyle aşırı derecede O2 üretimine neden olabilmektedir. Glutatyon peroksidaz (GSH-Px) ve SOD'a gibi diğer antioksidanlar örneğin katalaz (CAT), peroksidaz (POD), guaikol peroksidaz (GR), Glutatyon peroksidaz (GPX) ve askorbat peroksidaz (APX) enzimlerinin yanı sıra, askorbat glutatyon (AsA) ve tokoferol gibi bazı düşük moleküler maddelerde bitkilerde çevresel stresin zararını azaltmak için Se kullanıldığında işlev görebilir. Bu antioksidanlar, hidrojen peroksit (H2O2) temizlemesinden büyük ölçüde sorumludur. Stres koşullarında bitkilerde Se'nin APX ve katalaz (CAT) enzimini, özellikle de CAT'i önemli bir şekilde etkin hale getirdiği gözlenmektedir. Optimum düzeydeki Se ilavesinin, antimon ( $\mathrm{Sb}$ ) stresi koşullarında çeltik bitkisi, kurşun (Pb) stresinde bakla bitkisi, tuz ve kuraklık stresi koşullarında kolza bitkisi ve yüksek sıcaklık stresinde sorgum bitkisinde malondialdehit birikimini engellediği gözlenmiştir. Bitkiler çevresel strese maruz kaldıklarında, kloroplastlar zarar görmekte ve bu da fotosentezin olumsuz yönde etkilenmesine neden olmaktadır. Bununla birlikte, uygun Se miktarının eklenmesi kloroplastlara verilen zararı azaltabilir ve klorofil içeriğini artırabilir. Bununla birlikte, fazla Se, bitkilerde fotosentez sistemine zararı artırabilir, engelleyebilir ve fazla nişasta üretimi ile sonuçlanabilir (Feng ve ark., 2013).

\section{Tuzluluk}

Genel olarak tuzlu koşullarda Se durumu değerlendirildiğinde; Se-akümülatör bitkiler selenatı sülfat formunda aldığı için sülfattan kaynaklanan tuzluluğun bitki türlerine bağlı olarak selenat alımını büyük ölçüde engellediği vurgulanmıştır. Buna karşın klordan kaynaklanan tuzluluğun selenat alımı üzerinde sülfat tuzluluğundan çok daha az etkisi bulunduğu ve artan tuz seviyeleri ile birlikte sürgünlerde Se birikiminde azalmaya neden olduğu belirtilmiştir (Hasanuzzaman vd., 2010). Bu nedenle, Se uygulaması ile tuzluluk stresinin azaltıldığı çok sayıda çalışmada belirtilmiştir (Kong vd., 2005; Djanaguiraman vd., 2005; Hawrylak-Nowak, 2009). Aynı zamanda, bitki besin elementleri ile karşılıklı ilişkileri değerlendirildiğinde $\mathrm{N}, \mathrm{P}, \mathrm{Ca}$ ve $\mathrm{Mg}$ alımını artırdığı ve Na/K oranını azalttığı saptanmıştır. Öncelikle Se tuzlu koşullarda lipid peroksidasyona karşı hücre membranlarını korumaktadır. Se'un olumlu etkileri hücresel düzeyde antioksidan etkileri üzerine yoğunlaşmıştır. Tuzlu koşullarda uygulanan Se'un askorbat, katalaz, SOD, POD ve glutatyon gibi antioksidan enzimleri artırdığı buğday (Elkelish vd., 2019), kolza (Hashem vd., 2013) ve kuzukulağı (Kong vd., 2005) bitkilerinde saptanmıştır. Öte yandan Se uygulaması ile tuzlu koşullarda prolin ve çözünür şeker içeriğinin arttığı belirtilmiştir (Şekil 3) (Hashem vd., 2013; Elkelish vd., 2019).

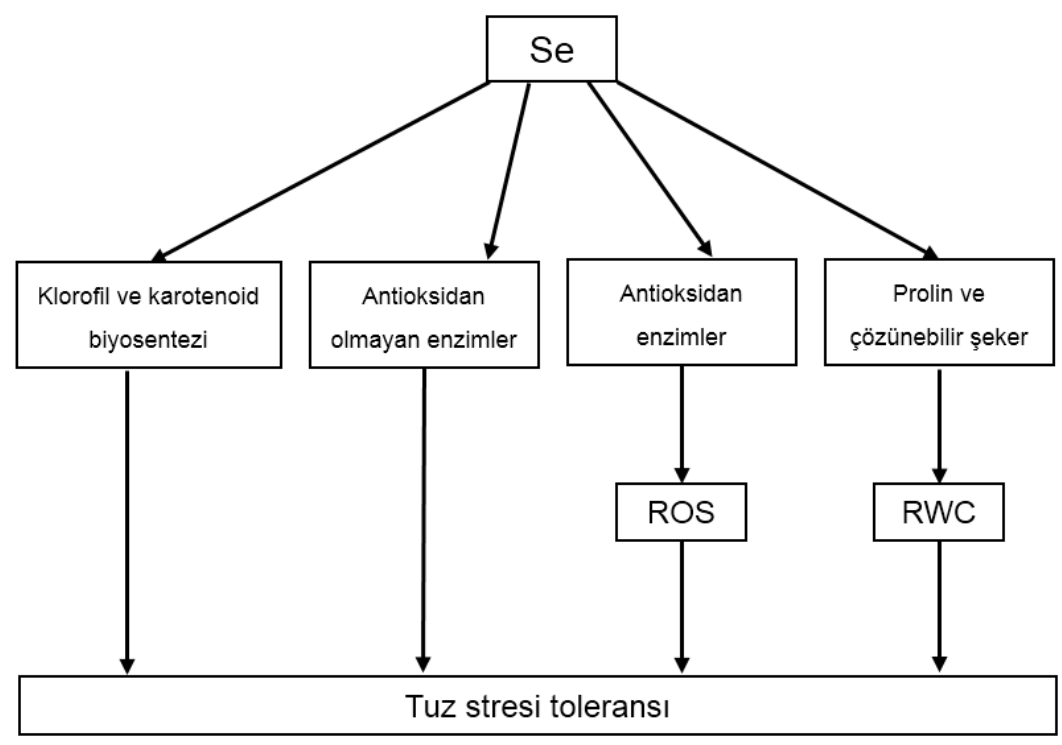

Şekil 3. Tuz stresi toleransında selenyumun rolü (ROS: Reaktif oksijen türleri, RWC: Nisbi nem içeriği) (Elkelish vd., 2019'dan değiştirilerek). 


\section{A ğır Metal Stresi}

Ağır metaller toksik etkileri nedeniyle bitkilerde transpirasyon, stoma hareketleri, su alımı, fotosentez, enzim aktivitesi, çimlenme, protein sentezi, membran stabilitesi, hormonal denge gibi birçok fizyolojik olayı olumsuz yönde etkilemektedir. Toksik etkiler metalden metale değişebildiği gibi, organizmadan organizmaya da değişebilmektedir (Haktanır ve Arcak, 1998).

Ağır metal stresinin fotosentezi olumsuz yönde etkileyerek bitkilerdeki kuru madde sentezini etkilediği vurgulanmıştır. Fotosentez mekanizmasında özellikle 1şık evrelerinde elektron transferinin engellendiği saptanmıştır. Ağır metaller enzim ve membran proteinlerindeki SH gruplarına geri dönüşümsüz bağlanırlar. Se uygulaması ile kloroplastlarda metal-protein kompleksi olan enzimler olumlu yönde etkilenmekte ve protein enzimlerinin aktivasyonunu destekleyen membran yapısının pozitif yönde değişmesi ortaya çıkmaktadır. Selenyumun ağır metal stresinde koruyucu rolü Şekil 4’te özetlenmiştir (Sieprawska vd., 2015).

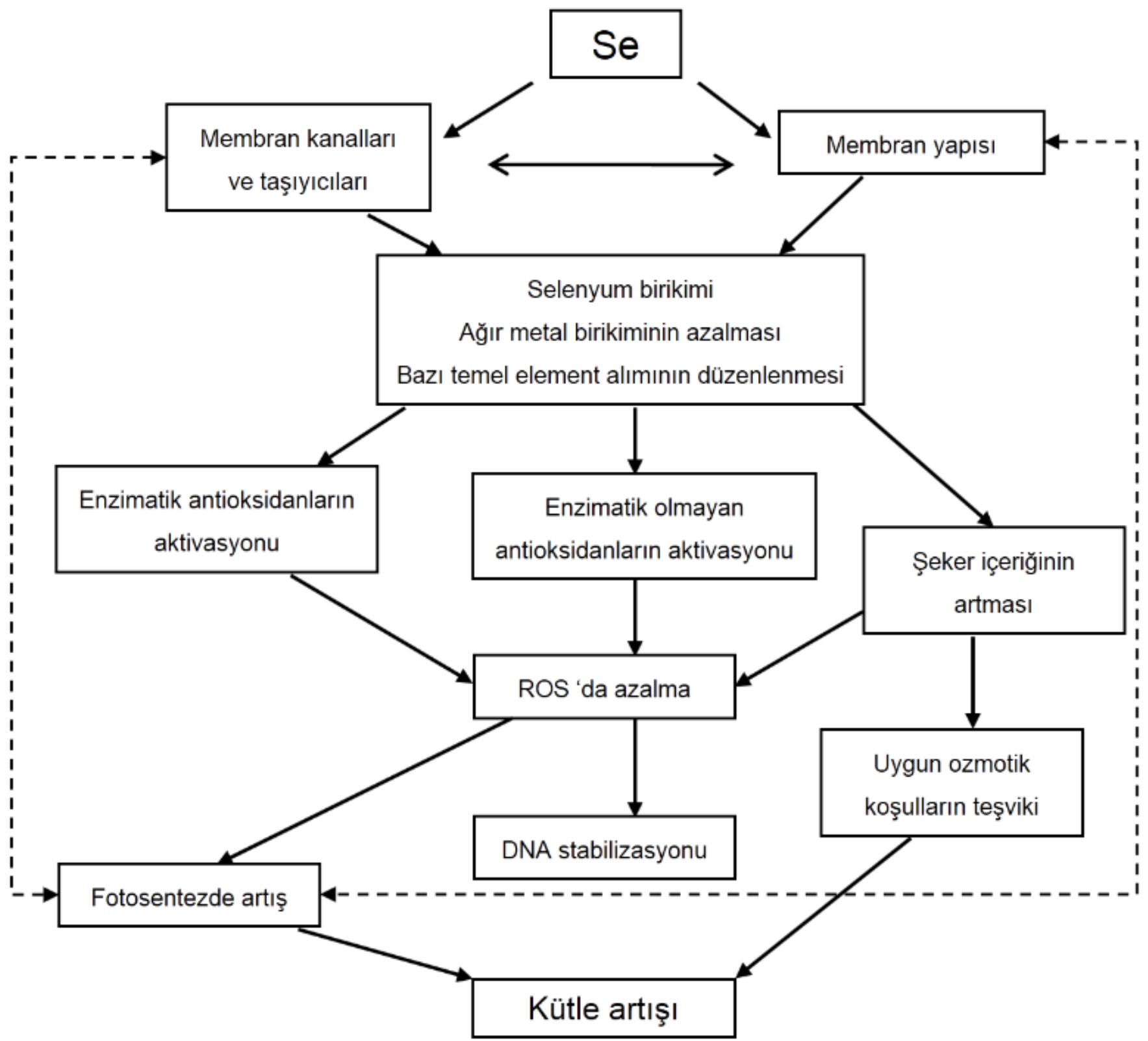

Şekil 4. Stres koşullarına maruz kalan bitkilerin bazı biyokimyasal ve fizyolojik özellikleri üzerine selenyumun etkisi. Kesikli çizgiler selenyum uygulamasında membran lipidlerinin fotosentez üzerine doğrudan etkisini göstermektedir (Sieprawska vd., 2015'den değiştirilerek).

Çeşitli araştırıcılar ağır metal stresi koşullarında Se'nin bitkilerde toksik etkiyi önleyebileceğini vurgulamışlardır (Vorobets, 2006; Srivastava vd., 2009; Cartes vd., 2010). Se'nin koruyucu etkilerinin toksik olmayan Se-metal komplekslerinin oluşumundan kaynaklandığı öne sürülmüştür. $\alpha$-tokoferol artışının, kloroplastlardaki singlet oksijen türlerinin atılmasını desteklediğinden bitkilerin stres toleransını arttırdığı bildirilmiştir. Bu nedenle, Cd'ye maruz kalan bitkilerde Se uygulamasının, stres koşullarına adaptasyonda yardımcı olduğu ve $\alpha$-tokoferolün artmasına neden olduğu (Hasanuzzaman vd., 2010) ve As kaynaklı streste düşük dozada Se uygulamasının oksidatif zararı azalttığı (Pandey ve Gupta, 2015) gözlenmiştir. Se uygulamasının malondialdehit (MDA) içeriğini ve Cd'nin sürgünlere doğru taşınımını ve ağır metaller tarafından tetiklenen oksidatif stresi azalttığı ortaya çıkmıştır (Pedrero vd.,2008; 
Hasanuzzaman vd., 2010). Benzer şekilde Sb stresi koşullarında çeltik bitkisinde ve Pb stresinde bakla bitkisinde serbest radikallerin etkileri ile makro moleküllerin oksidatif hasarı sonucunda açığa çıkan MDA birikimini engellediği gözlenmiştir (Feng vd., 2013).

\section{Kuraklık}

Kuraklık ve Se uygulamalarını birlikte ele alan çok sayıda çalışma yürütülmüş ve çoğunlukla serbest oksijen radikallerine karşın antioksidan tepki değerlendirilmiştir. Kurak koşullar altında selenyum uygulandığında SOD, POD, CAT, AsA ve GSH gibi antioksidan ve antioksidan olmayan çok sayıda enzimin arttığı (Xiaoqin vd., 2009; Hasanuzzaman vd., 2010; Keling vd., 2013; Habibi, 2013; Proietti vd., 2013; Ibrahim, 2014) ve MDA’nın özellikle kök içeriğinde azaldığı (Yao vd., 2009) gözlemlenmiştir. Fotosentezde PSII'nin fotokimyasal etkinliğinin ve stoma iletkenliğinin artışına (Tadina vd., 2007) bağlı olarak biyokütlenin kök aktivitesinin, prolin, karotenoid ve klorofil içeriğinin arttığ (Yao vd., 2009) saptanmıştır. Bitkinin organik bileşik kompozisyonundaki değişiklikler incelendiğinde ise toplam karbonhidrat ve protein içeriğinin (Emam vd., 2014; İbrahim, 2014) ve organik olmayan Ca ve P gibi osmotik düzenleyici rolü olan bileşiklerin arttığ (İbrahim, 2014) vurgulanmıştır. Tüm bu olumlu etkilere karşın özellikle düşük dozda kuraklık stresi altındaki bitkilerin büyüme parametrelerini etkilemediği belirtilmiştir (Sieprawska vd., 2015).

\section{Soğuk Stresi}

Selenyumun bitkilerin direncini ve antioksidan kapasitesini arttırmakla birlikte, soğuk stresinde de bitkilerdeki rolü ortaya konulmuştur. Chu vd., (2010) soğuk stresi altında buğdaylara $1.0 \mathrm{mg} \mathrm{kg}^{-1} \mathrm{Se}$ uygulamasının POD ve CAT aktivitelerindeki artışlara bağlı olarak MDA içeriğini, $\mathrm{O}_{2}^{-}$üretim oranını ve membran lipid peroksidasyonu önemli ölçüde azalttığını saptamışlardır. Sonuçta, soğuk stresi koşullarında buğday bitkisine selenyum uygulamasının koruyucu etkisi olduğunu vurgulamıştır. Diğer bir farklı çalışmada, yapraklara uygulanan selenyum miktarı $20 \mu \mathrm{M}$ 'na çıkarılmış ve optimum 2.5-10 $\mu \mathrm{M}$ Se dozunun prolin miktarını artırırken MDA içeriğini azalttığı saptanmıştır. Ancak bu durumun aksine $20 \mu \mathrm{M}$ 'un üzerinde selenyum uygulaması bitkilerin köklerinde ve yapraklarında MDA içeriğini artırmıştır. Aynı çalışmada, kısa süreli soğuk stresi altında, selenyum uygulaması ile klorofil ve karotenoidlerin içeriğinde önemli bir değişiklik gözlenmemiştir (Hawrylak-Nowak vd., 2010).

\section{Gen Ekspresyonu}

Abiotik strese bitkinin tepkisi birçok gen ve biyokimyasal moleküler mekanizmaya bağlı olarak değişmektedir. Strese neden olan genlerin işlevleri, moleküler mekanizmalarını ve tepkilerini anlamak ve gen manipülasyonu ile bitkilerin stres toleransını geliştirme açısından önemlidir. Burada, abiotik stres tepkilerine yüzlerce genin katıldığı düşünülmektedir (Ciarmiello vd., 2011). Bocchini vd. (2018) selenyumun abiyotik strese toleransla ilgili belirli bir gen sınıfının bir aktivatörü olabileceğini vurgulamaktadırlar. Özellikle, yaprak karotenoid içeriğini korumak için gerekli olan PSY (fitoen sentaz), kuraklık stresi sırasında önemli osmolitlerin seviyesini düzenleyen SDH (sorbitol dehidrojenaz) ve çevresel streslere biyokimyasal adaptasyonda temel rol oynayan ADH (alkol dehidrojenaz) genleri akla gelmektedir. Örneğin, Se-biofortifikasyonu, daha yüksek bir kuraklık toleransı oluşturarak mısır bitkilerinin kuraklık stres koşullarıyla başa çıkmasına yardımcı olmaktadır. Ayrıca Jiang vd. (2017), 1 $\mu \mathrm{M}$ Se ile muamele edilmiş mısır köklerinde ZmNHX1 ekspresyonunun, tuz stresi sonrası 24 saatte önemli ölçüde arttığını vurgulamışlardır. Özellikle, selenyum veya silisyum ile yapılan ön muamelenin hem TFs (transkripsiyon faktörleri), DREB2A, NAC5 ekspresyonunu, hem de OsRDCP1 genini içeren zincirin ekspresyonunu, OsCMO gibi çeltik kolin monooksigenaz ve dehidrin OsRAB16b gibi bazı kuraklık özel genlerini önemli bir şekilde artırdığı saptanmıştır. TFs ekspresyonu ve çalışılan genler, kuraklığa toleranslı IET 1444 çeşidinin Si-stresi altındaki sürgünlerinde belirgin bir şekilde arttığını göstermiştir. Hem Si hem de Se, DREB2A ve NAC (apikal olmayan merstem) TF yollarının aktivasyonu yoluyla OsCMO, OsRab16b ve OsRDCP1'in stres kaynaklı ekspresyonunu artırmaktadır (Khattab vd., 2014). Özellikle, NAC tipi TF OsNAC6, soğuk, kuraklık ve yüksek tuzluluk gibi abiotik stress koşullarında indüklenmektedir (Ciarmiello vd., 2011). Se, genellikle Se taşıyıcılarını ve birincil Se asimilasyonunda rol oynayan enzimleri ve toksik olmayan Se metabolitlerinin biyosentezini ve Se volatilizasyonunu oluşturan genlerin temel ekspresyonunu göstermektedir. Bununla birlikte, ıslah programlarına yardımcı olmak için yenilebilir dokularda Se konsantrasyonunu etkileyen, bilinen kromozomal kantitatif özellik lokuslarına (QTL) yönelik moleküler markerler geliştirilebilse de, bu değişimin temelini oluşturan gerçek genler büyük ölçüde bilinmemektedir (White, 2017).

Se uygulaması sonrasında, temel elementlerin seviyelerinde önemli azalmalar ile birlikte, ekspansin ve endotransglukosilaz/endohidrolaz (XHTs) genlerinin ekspresyon seviyelerinde de azalma gözlenmektedir. Se uygulaması yapılan bitkilerde, TCA döngüsü ara maddeleri ve sakkaroz, glukoz ve fruktoz gibi şekerlerde ayrıca hücre duvarı metabolizması ve birkaç temel besin maddesinin değişmiş seviyeleri ile ilişkili genlerin down regülasyonunda değişiklik ortaya çıkmaktadır. Gözlemler sonucu bitkilerde yavaş büyüme, karbon kaynaklarının korunmasına neden olarak ve stres koşullarına daha ılımlı bir şekilde adapte olmayı sağlamaktadır (Ribiero vd., 2016). Se'nin bu koruyucu etkileri, antioksidan etkisinden veya Se'nin, antioksidan aktivitede sorumlu genlerin ekspresyonu ve savunma tepkilerinden kaynaklanabilir. Bitkiler, gen ekspresyonundaki değişiklikler nedeniyle biyokimyasal ve fizyolojik işlemlerin değişikliklerini içeren sıcaklık stresi ile başa çıkmak için bir dizi yanıt geliştirmiştir. Se hiperakümülatörü Stanleya pinnata da, ikincil Se akümülatörü Stanleya albescens'e kıyasla kükürt alımı ve asimilasyonu, antioksidan aktiviteleri ve savunma ile ilişkili rol oynayan genlerin ekspresyonu daha yüksektir. Özellikle, hiperakümülatör türler, hem Se varlı̆̆ında hem de Se yokluğunda BiP gibi Hsp ve lüminal şaperonları kodlayan genler için ilgili türlerden daha yüksek bir ekspresyon göstermektedir (Malerba ve Cerena, 2018). Liu vd. (2017) mor marulda düşük Se konsantrasyonlarının antosiyanin birikimini teşvik edebileceğini ve F3H ve UFGT genlerinin kilit bir rol oynadığını vurgulamışlardır. Bu nedenle selenyumun antosiyanin birikimi ve antosiyanin sentezinin moleküler düzenlemesi üzerindeki etkisi temel olarak F3H ve UFGT geninin ekspresyon seviyelerinden kaynaklanmaktadır. 


\section{Sonuç}

Kuraklık, yüksek ve düşük sıcaklıklar, tuzluluk, ağır metal, UV, su taşkınları ve oksidatif stres gibi abiotik stres koşulları hücrede fizyolojik hasara yol açarak, bitki verimini önemli derecede azaltmaktadır. Bitkiler stres koşullarına tepki olarak çeşitli proteinler, antioksidanlar ve çözeltiler üretmektedirler. Birçok kültür bitkisinde bu bileşiklerden sorumlu genler geliştirilerek örneğin kuraklık ve tuzluluk toleransına neden olan çeşitli genler tanımlanarak, bu genleri içeren transgenik bitkilerin geliştirilmesi sonucu bu bitkiler abiotik stres koşullarında değerlendirilmektedir. Selenyumun (Se) insanlar, hayvanlar ve bakteriler için bir mikro besin maddesi olmasına rağmen bitkiler için gerekliliği hala tartışılmaktadır. Fakat selenosistein gibi selenoproteinlerin bitkilerde gözlenmesi, selenyumun bitkiler için de gerekli bir element olduğunu göstermektedir. $\mathrm{Bu}$ çalışma Se alımı, metabolizması ve abiyotik stres koşullarında selenyumun rolünü aydınlatmaya odaklanmıştır. Se'nin düşük dozlardaki yararlı etkisinden ve abiyotik stres koşullarında Se-hiperakümülatör bitkilerinin kullanılabileceği üzerinde durulmuştur. Ayrıca abiyotik stres koşullarına maruz kalan bitkilerde düşük dozlarda selenyum uygulamasının koruyucu rolünün antioksidan savunma sistemlerinin uyarılmasından ya da antioksidan aktivite ve savunma tepkilerinde belirtilen genlerin ekspresyonu üzerindeki etkisinden kaynaklandığı vurgulanmıştır.

\section{Kaynakça}

Bocchini, M., D’Amato, R., Ciancaleoni, S., Fontanella, M. C., Palmerini, C. A., Beone, G. M., Onofri A., Negri V., Marconi G., Albertini E., Businelli, D. (2018). Soil selenium (Se) biofortification changes the physiological, biochemical and epigenetic responses to water stress in Zea mays L. by inducing a higher drought tolerance. Frontiers in Plant Science, 27 (9): 389.

Brown, K.M., Arthur, J.R. 2001. Selenium, selenoproteins and human health: a review. Public Health Nutrition, 4: $593-599$.

Cappa, J. J., Pilon-Smits, E.A.H. 2014. Evolutionary aspects of hyperaccumulation. Planta, 239: 267-275.

Carey, A.M., Scheckel, K.G., Lombi, E., Newville, M., Choi, Y., Norton, G.J., Charnock, J.M., Feldman, J., Price, A.H., Meharg, A.A. 2010. Grain unloading of arsenic species in rice (Oryza sativa L.). Plant Physiology, 152: 309-319.

Carey, A., Lombi, E., Donner, E. et al. A review of recent developments in the speciation and location of arsenic and selenium in rice grain. Anal Bioanal Chem 402, 3275-3286 (2012).

Cartes, P., Jara, A.A., Pinilla, L., Rosas, A., Mora, M.L. 2010. Selenium improves the antioxidant ability against aluminium-induced oxidative stress in ryegrass roots. Annals of Applied Biology, 156: 297-307.

Chu, J., Yao, X., Zhang, Z. 2010. Responses of wheat seedlings to exogenous selenium supply under cold stress. Biological Trace Element Research, 136: 355-363.

Ciarmiello, L.F., Woodrow, P., Fuggi, A., Pontecorvo, G., Carillo, P. 2011. Plant Genes for Abiotic Stress. Shanker, A., Venkateswarlu B. (Eds). Abiotic Stress in Plants - Mechanisms and Adaptations. InTech, Croatia, pp. 283-308.

Çakmak İ., Öztürk L., Başağa H., Cekic C., Taner S., Irmak S., Geren H., Kılıç H., Aydın N., Avcı M., Gezgin S. 2009. Türkiye'de seçilmiş bölgelerde buğdayların ve toprakların selenyum konsantrasyonunun araştırılması, selenyum gübrelemesine buğdayın reaksiyonu ve selenyumca zengin genotiplerin fizyolojik olarak karakterizasyonu, TÜBİTAK Projesi Sonuç Raporu. 178 s.

Djanaguiraman, M., Devi, D.D., Shanker, A.K., Seeba, A., Bangarusamy, U. 2005. Selenium-an antioxidative protectant in soybean during senescence. Plant and Soil, 272: 77-86.

Ekelund N.G.A., Danilov, R.A. 2001. The influence of selenium on photosynthesis and "light-enhanced dark respiration" (LEDR) in the flagellate Euglena gracilis after exposure to ultraviolet radiation. Aquatic Sciences, 63: 457-465.

Elkelish, A.A., Soliman, M.H., Alhaithlould, H.A., El-Esawi, M.A. 2019. Selenium protects wheat seedlings against salt stressmediated oxidative damage by up-regulating antioxidants and osmolytes metabolism. Plant Physiology and Biochemistry, 137: 144-153.

Emam, M.M., Khattab, H.E., Helal, N.M., Deraz, A.E. 2014. Effect of selenium and silicon on yield quality of rice plant grown under drought stress. Australian Journal of Crop Science, 8: 596-605.

Feng, R., Chaoyang, W., Tu, S. 2013. The roles of selenium in protecting plants against abiotic stresses. Environmental and Experimental Botany, 87: 58-68.

Feng, R., Wei, C., Tu, S., Sun, X. 2009. Interactive effects of selenium and arsenic on their uptake by Pteris vittata L. under hydroponic conditions, Environmental and Experimental Botany, 65: 363-368.

Goldhaber, S.B. 2003. Trace element risk assessment: essentiality vs. toxicity. Regulatory Toxicology and Pharmacology, 38: 232242.

Gökbulut, T. 2010. Bazı buğday çeşitlerinde selenyum birikimi ve selenyum toksisitesinin antioksidan enzim aktivitesine etkisi. Yüksek Lisans Tezi. Erciyes Üniversitesi Fen Bilimleri Enstitüsü, 112 s, Kayseri.

Habibi, G. 2013. Effect of drought stress and selenium spraying on photosynthesis and antioxidant activity of spring barley. Acta Agriculturae Slovenica, 101: 31-39.

Haktanır, K., Arcak, S. 1998. Çevre Kirliliği. Ankara Üniversitesi Ziraat Fakültesi, Ders Kitabı, Yayın No: 1503 , 457 s, Ankara.

Hamilton, S. J. 2004. Review of selenium toxicity in the aquatic food chain. Science of The Total Environment, $326: 1-31$.

Harmankaya, M. 2009. Orta Anadolu Bölgesinde Toprakların ve Buğdayın Selenyum Düzeyinin Belirlenmesi ve Selenyum Gübrelemesine Farklı Buğday Genotiplerinin Tepkisinin Araştırılması. Doktora Tezi. Selçuk Üniversitesi Fen Bilimleri Enstitüsü, 129 s, Konya.

Harris, J., Schneberg, K.A., Pilon-Smits E.A. 2014. Sulfur-selenium-molybdenum interactions distinguish selenium hyperaccumulator Stanleya pinnata from non-hyperaccumulator Brassica juncea (Brassicaceae). Planta 239: 479-491.

Hartikainen, H., Xue, T. 1999. The promotiv effect of selenium on plant growth as triggered by ultraviolet radiation. Journal of Environmental Quality, 28: 1372-1375. 
Hasanuzzaman, M., Hossain, M.A., Fujita, M. 2010. Selenium in higher plants: physiological role, antioxidant metabolism and abiotic stress tolerance. Journal of Plant Sciences, 5: 354-375.

Hashem, H.A., Hassanein, R.A., Bekheta, M.A., El-Kady, F.A. 2013. Protective role of selenium in canola (Brassica napus L.) plant subjected to salt stress. The Egyptian Journal of Experimental Biology (Botany), 9 (2): 199-211.

Hawrylak-Nowak, B. 2009. Beneficial effects of exogenous selenium in cucumber seedlings subjected to salt stress. Biological Trace Element Research, 132: 259-269.

Hawrylak-Nowak B., Matraszek, R., Szymańska, M. 2010. Selenium modifies the effect of short-term chilling stress on cucumber plants. Biological Trace Element Research, 138 (1-3): 307-15.

Irmak, S., Semercioğlu, T. 2012. Çukurova Bölgesi'nde Yetiştirilen Bazı Buğday (Triticum spp.) Çeşitlerinde Toprak-Bitki Selenyum İçeriği Arasındaki İlişki. Tarım Bilimleri Araştırma Dergisi 5 (2): 19-23.

Ibrahim, H. M. (2014). and Reduces Oxidative Stress on Drought-Stressed Wheat (T riticum aestivum L.) Plants. Asian Journal of Plant Sciences, 13(3), 120-128.

Ibrahim, M.F.M., Ibrahim, H.A. 2016. Assessment of Selenium Role in Promoting or Inhibiting Potato Plants under Water Stress. Journal of Horticultural Science and Ornamental Plants, 8 (3): 125-139.

Jiang, C., Zu, C., Shen, J., Shao, F., Li, T. 2015. Effects of selenium on the growth and photosynthetic characteristics of flue-cured tobacco (Nicotiana tabacum L.). Acta Societatis Botanicorum Poloniae, 84 (1): 71-77.

Jiang, C., Zu, C., Lu, D., Zheng, Q., Shen, J., Wang, H., Li, D. 2017. Effect of exogenous selenium supply on photosynthesis, Na+ accumulation and antioxidative capacity of maize (Zea mays L.) under salinity stress. Scientific Reports, 7:42039. doi: $10.1038 /$ srep42039.

Kacar, B., Katkat, A.V. 1998. Bitki Besleme. Uludağ Üniversitesi Güçlendirme Vakfi Yayın No: 127, VİPAŞ Yayınları: 3, Bursa.

Keling, H., Ling, Z., Jitao, W., Yang, Y. 2013. Influence of selenium on growth, lipid peroxidation and antioxidative enzyme activity in melon (Cucumis melo L.) seedlings under salt stress. Acta Soietatis Botanicorum Poloniae, 82: 193-197.

Khattab, H.I., Emam, M.A., Emam, M.M., Helal, N.M., Mohamed, M.R. 2014. Effect of selenium and silicon on transcription factors NAC5 and DREB2A involved in drought-responsive gene expression in rice. Biologia Plantarum, 58: $265-273$.

Kikkert, J., Berkelaar, E. 2013. Plant uptake and translocation of inorganic and organic forms of selenium. Archives Environmental Contamination and Toxicology, 65: 458-465.

Kong, L., Wang, M., Bi, D. 2005. Selenium modulates the activities of antioxidant enzymes, osmotic homeostasis and promotes the growth of sorrel seedlings under salt stress. Plant Growth Regulation, 45: 155-163.

Liu, D., Li, H., Wang, Y., Ying, Z., Bian, Z., Zhu, W., ... \& Jiang, D. (2017). How Exogenous Selenium Affects Anthocyanin Accumulation and Biosynthesis-Related Gene Expression in Purple Lettuce. Polish Journal of Environmental Studies, 26(2).

Lyons, G., Stangoulis, J., Graham, R. 2003. High-Selenium Wheat: Biofortification For Better Health. Nutrition Research Reviews, 16: $45-60$.

Malerba, M., \& Cerana, R. (2018). Effect of selenium on the responses induced by heat stress in plant cell cultures. Plants, 7(3), 64.

Malik, J.A., Goel, S., Kaur, N., Sharma, S., Singh, I., Nayyar, H. 2012. Selenium antagonises the toxic effects of arsenic on mungbean (Phaseolus aureus Roxb.) plants by restricting its uptake and enhancing the antioxidative and detoxification mechanisms. Environmental and Experimental Botany, 77: 242-248.

Manaf, H.H. 2016. Beneficial effects of exogenous selenium, glycine betaine and seaweed extract on salt stressed cowpea plant. Annals of Agricultural Sciences, 61: 41-48.

Natasha, N., Shahid, M., Niazi, N.K., Khalid, S., Murtaza, B., Bibi, I., Rashid, M.I. 2018. A critical review of selenium biogeochemical behavior in soil-plant system with an inference to human health. Environmental Pollution, 234: 915-934.

Pandey, C., Gupta, M. 2015. Selenium and auxin mitigates arsenic stress in rice (Oryza sativa L.) by combining the role of stress indicators, modulators and genotoxicity assay. Journal of Hazardous Materials, 287: 384-391.

Pedrero, Z., Madrid, Y., Hartikainen, H., Camara, C. 2008. Protective effect of selenium in broccoli (Brassica oleracea) plants subjected to cadmium exposure. Journal of Agricultural and Food Chemistry, 56: 266-271.

Proietti, P., Nasinia, L., Del Buonoa, D., D'amatoa, R, Tedeschinib, E, Businellia, D. 2013. Selenium protects olive (Olea europaea L.) from drought stress. Scientia Horticulturae, 164: 165-171.

Ribeiro, D. M., Silva Junior, D. D., Cardoso, F. B., Martins, A. O., Silva, W. A., Nascimento, V. L., \& Araújo, W. L. (2016). Growth inhibition by selenium is associated with changes in primary metabolism and nutrient levels in Arabidopsis thaliana. Plant, cell \& environment, 39(10), 2235-2246.

Schertl, P., \& Braun, H. P. (2014). Respiratory electron transfer pathways in plant mitochondria. Frontiers in Plant Science, 5, 163

Seppänen, M., Turakainen, M., Hartikainen, H. 2003. Selenium effects on oxidative stress in potato. Plant Science. 165: 311-319.

Shekari, F., Abbasi, A, Mustafavi, S.H. 2015. Effect of silicon and selenium on enzymatic changes and productivity of dill in saline condition. Journal of Saudi Society of Agricultural Sciences, 16: 367-374.

Sieprawska, A., Kornaś, A, Filek, M. 2015. Involvement of selenium in protective mechanisms of plants under environmental stress conditions-review. Acta Biologica Cracoviensia Series Botanica, 57: 1-12.

Sillanpää, M., Jansson, H. 1992. Status of Cadmium, Lead, Cobalt and Selenium in Soils and Plants of Thirty Countries, FAO Soils Bulletin 65 Rome, , Italy: Food and Agricultural Organization of the United Nations.

Skillman, J.B., Griffin, K.L., Earll, S., Kusama, M. 2011. Photosynthetic productivity: can plants do better? In: Pirajin JCM (Eds) Thermodynamics-systems in equilibrium and non-equilibrium. InTech, Shangai, pp 36-68.

Srivastava, M., Maa, L.Q., Rathinasabapathib, B., Srivastava P. 2009. Effects of selenium on arsenic uptake in arsenic hyperaccumulator Pteris vittata L. Bioresource Technology. 100 (3): 1115-1121.

Tadina, N., Germ, M., Kreft, I., Breznik, B., \& Gaberščik, A. (2007). Effects of water deficit and selenium on common buckwheat (Fagopyrum esculentum Moench.) plants. Photosynthetica, 45(3), 472-476. 
Turakainen, M., Hartikainen, H., Ekholm, P., Seppanen, M. 2006. Distribution of selenium in different biochemical fractions and raw darkening degree of potato (Solanum tuberosum L.) tubers supplemented with selenate. Journal of Agricultural and Food Chemistry, 54: 8617-8622.

Türkmen, N. 2010. Toprak özellikleri ile selenyum yarayışılılı̆ı arasındaki ilişkiler ve sarımsağın selenyum ile zenginleştirilmesi. Doktora Tezi. Ankara Üniversitesi Fen Bilimleri Enstitüsü, 192 s, Ankara.

Valkama, E., Kivimäenpää, M., Hartikainen, H., Wulff, A. 2003. The combined effects of enhanced UV-B radiation and selenium on growth, chlorophyll fluorescence and ultrastructure in strawberry (Fragaria x ananassa) and barley (Hordeum vulgare) treated in the field. Agricultural and Forest Meteorology, 120: 267-278.

Vorobets, N. 2006. Glutatione peroxidase activity in sunflower shoots exposed to lead and selenium. Annales Universitatis Mariae Curie-Sklodowska, 19: 151-154.

Wang, C.Q. 2011. Water-stress mitigation by selenium in Trifolium repens L. Journal of Plant Nutrition and Soil Science, 174 (2): 276-282.

White, P.J. 2017. The Genetics of Selenium Accumulation by Plants. In: Pilon-Smits E., Winkel L., Lin ZQ. (Eds) Selenium in plants. Plant Ecophysiology, vol 11. Springer, Cham.

Xiaoqin, Y., Jianzhou, C., Guangyin, W. 2009. Effects of drought stress and selenium supply on growth and physiological characteristics of wheat seedlings. Acta Physiologiae Plantarum, 31: 1031-1036.

Yao ,X., Chu, J., He, X., Ba, C. 2011. Protective role of selenium in wheat seedlings subjected to enhanced UV-B radiation. Russian Journal of Plant Physiology, 58 (2): 283-289.

Yao, X., Chu, J., Wang, G. 2009. Effects of selenium on wheat seedlings under drought stress. Biological Trace Element Research, 130: 283-290.

Zhu, Y.G., Pilon-Smits, E.A.H., Zhao, F.J., Williams, P.N., Meharg, A.A. 2009. Selenium in higher plants: understanding mechanisms for biofortification and phytoremediation. Trends Plant Science, 14: 436-442. 